\title{
Heterologous Expression of Functional Ptr ToxA
}

\author{
Robert P. Tuori, Thomas J. Wolpert, and Lynda M. Ciuffetti \\ Department of Botany and Plant Pathology, 2082 Cordley Hall, Oregon State University, Corvallis 97331, \\ U.S.A. \\ Accepted 5 January 2000.
}

\begin{abstract}
Ptr ToxA, a proteinaceous host-selective toxin (HST) produced by the fungus Pyrenophora tritici-repentis, was expressed in Escherichia coli and purified as a polyhistidinetagged, fusion protein (NC-FP). NC-FP, consisting of both the $\mathrm{N}$ and $\mathrm{C}$ domains of the ToxA open reading frame (ORF), is produced as an insoluble protein in $E$. coli at approximately 10 to $16 \mathrm{mg}$ per liter of culture. Following in vitro refolding, $\mathrm{NC}$-FP elicits cultivar-specific necrosis in wheat, with a specific activity similar to that of native Ptr ToxA. A fusion protein consisting of only the $\mathrm{C}$ domain has approximately 10 to $20 \%$ of the activity of native Ptr ToxA. These data suggest that (i) the $\mathbf{N}$ domain is important for maximal activity of Ptr ToxA, (ii) the $\mathbf{N}$ domain does not function to eliminate activity of the protoxin, and (iii) post-translational modifications of Ptr ToxA are not essential for activity. A C domain construct with a cysteine residue mutated to glycine is inactive. This, plus the observation that toxin activity is sensitive to reducing agents, provides evidence that the two cysteine residues in Ptr ToxA are involved in a disulfide bond that is essential for activity. The heterologous expression of $P \operatorname{tr}$ ToxA provides a valuable tool for addressing a number of issues such as receptor binding studies, structure/function studies, and screening wheat cultivars for disease resistance.
\end{abstract}

Ptr ToxA (syn. Ptr toxin, Ptr necrosis toxin, and ToxA) (Ciuffetti et al. 1998), a host-selective toxin (HST) produced by the fungus Pyrenophora tritici-repentis, is unlike other HSTs in that it is the protein product of a single gene (Ciuffetti et al. 1997). This protein was purified and characterized (Ballance et al. 1989; Tomas et al. 1990; Tuori et al. 1995; Zhang et al. 1997) and shown by mass spectroscopy to be a 13.2-kDa, heat-stable polypeptide that induces necrosis when infiltrated into sensitive wheat cultivars (Tuori et al. 1995). Because most HSTs are secondary metabolites, and are likely to be the products of multifunctional enzymes or biochemical pathways, the genetic analysis of their production is difficult and the heterologous expression of these toxins has not been accomplished. The transformation of a nontoxin-producing, nonpathogenic isolate of the fungus to a toxin-producing, pathogenic state was facilitated by the fact that Ptr ToxA is the product of a single gene and

Corresponding author: L. M. Ciuffetti; E-mail: ciuffetl@bcc.orst.edu

Current address of Robert P. Tuori: Boyce Thompson Institute, Tower Road, Ithaca, NY 14853, U.S.A. unequivocally demonstrated the causal role of this HST in pathogenicity (Ciuffetti et al. 1997).

P. tritici-repentis causes the economically important disease tan spot of wheat. The disease, which can lead to significant yield losses (Hosford 1982), has been reported worldwide and its occurrence is likely to increase as agriculture shifts to notill practices (Schuh 1990; Bailey and Duczek 1996). Although development of cultivars resistant to $P$. tritici-repentis is currently a goal of breeders (Cox et al. 1988; Riede et al. 1996), field screening for disease in response to the fungus is difficult due to environmental fluctuations (Francl 1995). However, because wheat cultivars that are sensitive to the Ptr ToxA protein respond to infection by $P$. tritici-repentis with tan necrosis, screening of wheat for sensitivity to Ptr ToxA may provide an easier and more reliable method to identify resistant germplasm (Riede et al. 1996). Ptr ToxA can be purified from cultures of $P$. tritici-repentis, yielding an average of $6 \mathrm{mg}$ of purified toxin per liter of culture filtrate (Tuori et al. 1995). This method, although reliable, is time consuming and labor intensive. Thus, expression of Ptr ToxA in Escherichia coli could provide an easier, less expensive method of toxin production.

The heterologous expression of Ptr ToxA was also pursued to elucidate the functional role of the pro-sequence of the Ptr ToxA gene. The ToxA open reading frame (ORF) encodes a pre-pro-protein with an $\mathrm{N}$-terminal signal peptide, followed by a dual domain pro-toxin. The pro-toxin consists of an approximately $4.3-\mathrm{kDa}$, anionic, N-terminal domain, or proregion, of unknown function and destiny, and a 13-2 kDa, cationic, C-terminal domain that is the mature, secreted Ptr ToxA protein (Ciuffetti et al. 1997). During the purification of Ptr ToxA protein, we observed an anionic toxic component that was chromatographically, electrophoretically, and immunologically distinct from Ptr ToxA (Tuori et al. 1995). Preliminary attempts at characterization indicated that it was likely to be proteinaceous, and smaller than Ptr ToxA. The possibility that the $\mathrm{N}$ domain of the pro-toxin is the observed anionic toxic component was investigated by attempting to express this domain separately.

pro-regions are common in secreted proteins and have been hypothesized to assist in folding, aid in secretion, and prevent activity prior to proteolytic cleavage (Eder and Fersht 1995). The role that the $\mathrm{N}$ domain plays in both the correct folding of Ptr ToxA and/or the suppression of activity prior to final processing was investigated by expressing the pro-toxin (i.e., the $\mathrm{N}$ and $\mathrm{C}$ domains together) in $E$. coli.

A requirement (if any) of post-translational processing for the necrosis-inducing activity of Ptr ToxA could be assessed by determining whether an active form of the protein could 
be produced from E. coli. It was reasoned that if an active form of the toxin were obtained, any processing that may occur in the native fungus would not be essential for the full activity of Ptr ToxA. Finally, we also sought to assess the feasibility of examining structure/function relationships for this protein through the expression of mutant forms of the toxin in E. coli.

\section{RESULTS}

\section{Expression and activity of initial constructs.}

Initial plasmids were constructed to express (i) the $\mathrm{N}$ domain of the ToxA ORF (N-FP), (ii) the C domain of the ToxA ORF (C-FP) (Fig. 1A), and (iii) the $\mathrm{N}$ and $\mathrm{C}$ domains of the ToxA ORF together (NC-FP) (Fig. 1A). Each construct was expressed as a fusion protein with a TEV protease recognition site (Parks et al. 1995) separating an N-terminal polyhistidinetag (HIS-tag) and the respective portion of the ToxA ORF (Fig. 1A). All constructs lacked the native ToxA signal sequence (the first 22 amino acids of the ORF). The aminoterminal position of the $\mathrm{N}$ domain, or pro-region of the Ptr ToxA pro-toxin, was based on signal peptide consensus sequence analysis (von Heijne 1986) and was predicted to be amino acid residue Asp-23 (Ciuffetti et al. 1997). Prior attempts at $\mathrm{N}$-terminal sequencing of Ptr ToxA (i.e., the $\mathrm{C}$ domain) indicated an N-terminal blockage. The amino-terminal position of mature Ptr ToxA, previously predicted to be after Arg-60 or after Gln-61 (Ciuffetti et al. 1997), was confirmed by treating purified Ptr ToxA with the enzyme pyroglutamate amino peptidase to remove a possible pyroglutamate residue from its $\mathrm{N}$ terminus. Following treatment, sequence information of Ptr ToxA was obtained corresponding to the amino acid sequence immediately following Gln-61. Thus, Gln-61 was concluded to be the correct assignment of the $\mathrm{N}$ terminus of mature Ptr ToxA.

Both the NC-FP and the C-FP were produced by E. coli in abundance (10 to $16 \mathrm{mg} / \mathrm{liter}$ ). Both proteins were found almost exclusively in the insoluble fraction, whether cells were grown at 30 or $37^{\circ} \mathrm{C}$ (data not shown). The isolation of inclusion bodies from bacterial cells produced preparations enriched for fusion proteins that were then solubilized in $8 \mathrm{M}$ guanidine $\mathrm{HCl}$, refolded in vitro, and affinity purified. The refolding procedure utilized in this study resulted in a wide range (5 to $50 \%$ ) of soluble protein recovered from the insoluble fraction for both the C-FP and NC-FP, with variation occurring among preparations. Following refolding and purification, the specific activity of the NC-FP was similar to that of native Ptr ToxA, while the C-FP consistently displayed approximately one-tenth to one-fifth the specific activity of native Ptr ToxA (Fig. 1B). Removal of the HIS-tag with TEV protease had no effect on the necrosis-inducing activity of either fusion protein. The NC-FP displays heat stability and resistance to reduction with $\beta$-mercaptoethanol similar to native Ptr ToxA (Fig. 1C). Boiling for $10 \mathrm{~min}$ or incubation in a reducing environment does not affect the activity of either protein. However, boiling in the presence of a reducing agent eliminates virtually all Ptr ToxA activity and the majority, although not all, of NC-FP activity. Ni affinity-purified NC-FP and C-FP appear as the predicted approximately $19.7 \mathrm{kDa}$ and approximately $15.4 \mathrm{kDa}$ bands in sodium dodecyl sulfate (SDS)-polyacrylamide gels, respectively (without treatment with TEV protease), and both react with antisera raised against purified Ptr ToxA in protein gel blot analysis (Fig. 2).

To assess the homogeneity and extent of possible deleterious modifications of the NC-FP, purified protein was sub-
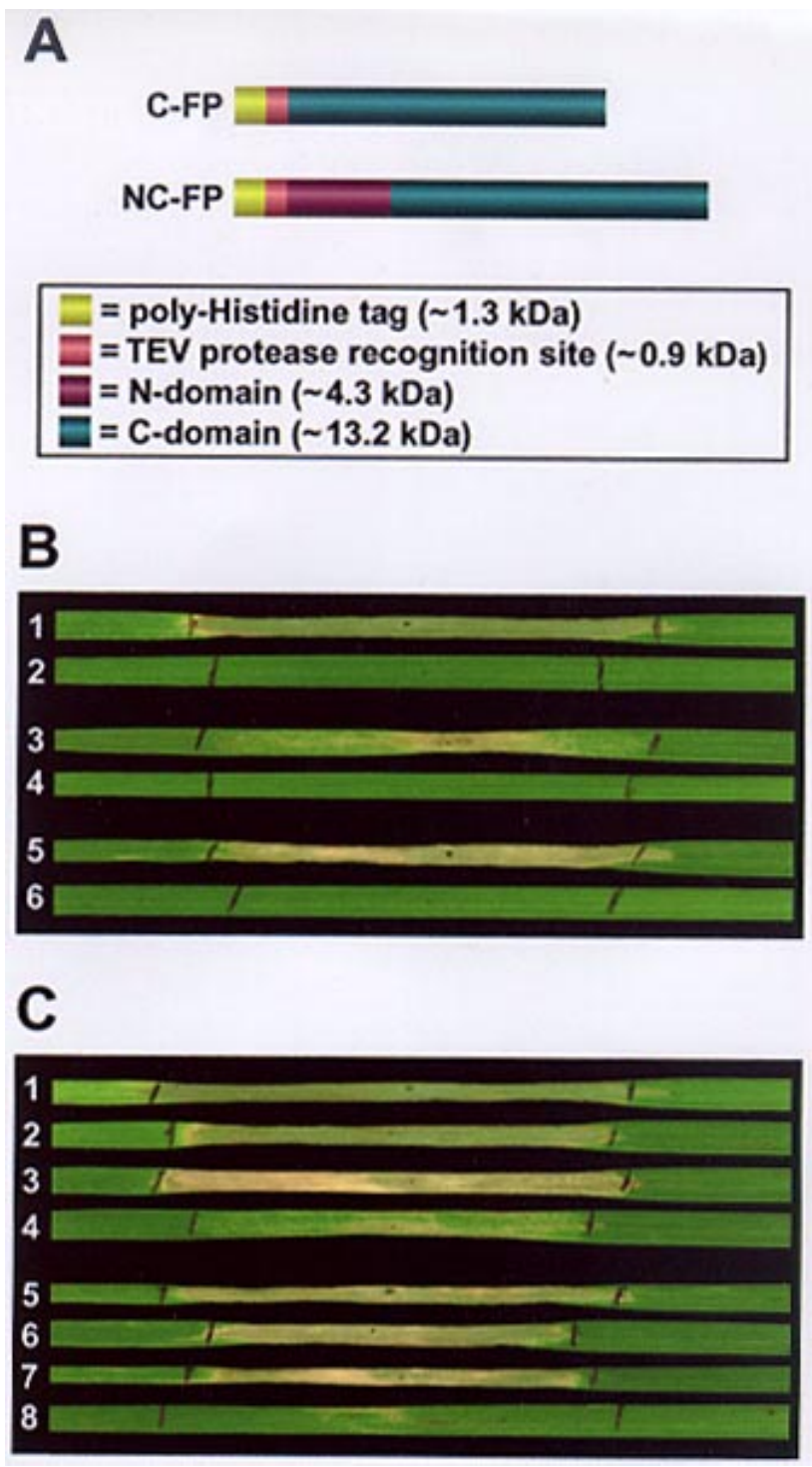

Fig. 1. Structure and bioassay of initial fusion proteins. A, Fusion protein constructs. An illustration of the initial fusion proteins expressed in Escherichia coli is shown with the constituent domains of the ToxA open reading frame with the polyhistidine tag and TEV protease recognition motif indicated. B, Leaf infiltration bioassay of NC-FP and C-FP. Leaves 1,3 , and 5 are the sensitive genotype (TAM-105); leaves 2, 4, and 6 are the insensitive genotype of wheat (Auburn). Leaves 1 and 2 were infiltrated with refolded, purified NC-FP at $1 \mu \mathrm{M}$; leaves 3 and 4 were infiltrated with refolded, purified C-FP at $1 \mu \mathrm{M}$; leaves 5 and 6 were infiltrated with purified Ptr ToxA at $1 \mu \mathrm{M}$ for comparison. All infiltrations were with uncleaved fusion proteins. $\mathbf{C}$, Heat and reduction sensitivity of NC-FP. Leaves of the sensitive genotype of wheat (TAM-105) are shown following infiltration with $1 \mu \mathrm{M}$ refolded, purified NC-FP (leaves 1 through 4) or Ptr ToxA (leaves 5 through 8). Leaves 1 and 5 were infiltrated with samples without additional treatments; leaves 2 and 6 were infiltrated with samples boiled for 10 min prior to infiltration; leaves 3 and 7 were infiltrated with samples treated with reducing agent prior to infiltration; leaves 4 and 8 were infiltrated with samples boiled for 10 $\min$ in the presence of reducing agent prior to infiltration. 
jected to matrix-assisted laser desorption/ionization time-offlight (MALDI-TOF) mass spectral analysis. Duplicate analyses were performed, each indicating a mass of $19,801 \mathrm{Da}( \pm 2)$ for the protein. The predicted molecular mass for the NC-FP, assuming a single internal disulfide bond, is 19,785 $\mathrm{Da}$. The NC-FP, therefore, has an unexpected mass increase of 16 Da. The actual sequence of NC-FP corresponded to the predicted amino acid sequence when purified NC-FP was subjected to direct amino acid sequencing, indicating that the protein is not N-terminally blocked.

The N-FP was not produced in detectable quantities. Upon induction, cultures harboring the plasmid for expression of this fusion protein appeared to stop growing and the protein was never detected in protein gel-blot analysis with either an alkaline phosphatase-Ni conjugate (Qiagen, Valencia, CA) for detection of polyhistidines or antisera raised against the NC-FP.

\section{Expression and activity of mutant constructs.}

In an attempt to overcome the inability to express the $\mathrm{N}$ domain independently in E. coli, a construct was designed for expression of the $\mathrm{N}$ and $\mathrm{C}$ domains of the ToxA ORF separated by a TEV recognition motif (N-TEV-C-FP; Fig. 3A). This would allow for cleavage into separate domains following refolding and purification. The N-TEV-C-FP was purified and refolded in the same way as the NC-FP, yielding equivalent quantities of protein with approximately the same specific activity (Fig. 3B). N-TEV-C-FP appears as the predicted size band (approximately $19.7 \mathrm{kDa}$ ) in SDS-polyacrylamide gels and reacts with antisera raised against purified Ptr ToxA in protein gel blot analysis (Fig. 2). Proteolytic cleavage at the TEV recognition site between the $\mathrm{N}$ and $\mathrm{C}$ domains of this fusion protein was attempted under a variety of reaction con-

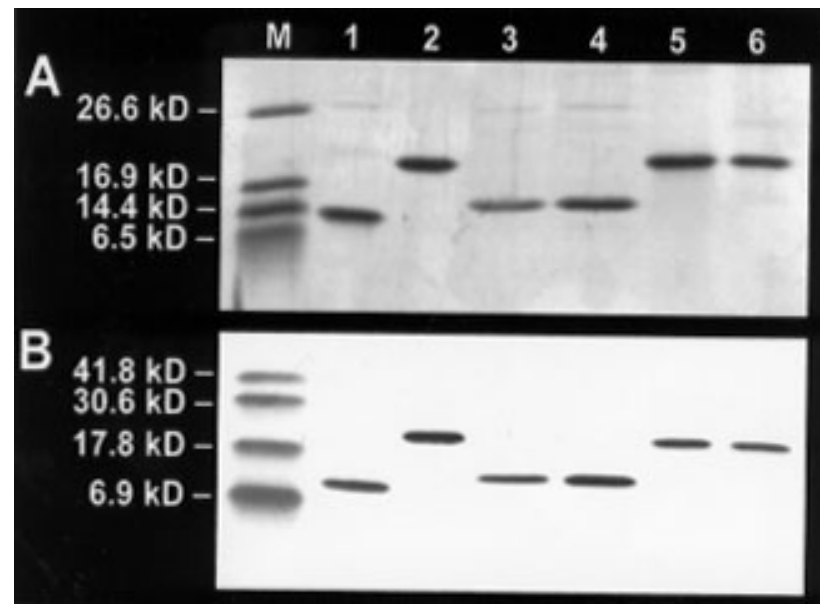

Fig. 2. Electrophoretic and immunoblot analyses of refolded, purified fusion proteins. A, Five-hundred-nanogram samples of each protein detected with Brilliant-Blue Colloidal (Sigma, St. Louis, MO) following electrophoresis in a $17 \%$ sodium dodecyl sulfate (SDS)-polyacrylamide gel. B, Western (immunoblot) analysis of 50-ng samples of each protein detected with anti-Ptr ToxA antibodies and alkaline phosphatase-conjugated secondary antibody, following electrophoresis in a $17 \%$ SDSpolyacrylamide gel and electroblotting onto a nitrocellulose membrane. A and B, Lane 1 is Ptr ToxA (13.2 kDa); lane 2 is NC-FP (approx. 19.7 $\mathrm{kDa}$ ); lane 3 is C-FP (approx. $15.4 \mathrm{kDa}$ ); lane 4 is $\mathrm{C}_{\text {mut-FP (approx. } 15.4}$ $\mathrm{kDa}$ ); lane 5 is N-TEV-C-FP (approx. $19.7 \mathrm{kDa}$ ); lane 6 is NCmut-FP (approx. $19.7 \mathrm{kDa}$ ); lane $\mathrm{M}$ is molecular weight markers. ditions. However, these attempts consistently resulted in a small percentage $(<10 \%)$ of the protein being cleaved as visualized by both silver staining following SDS-polyacrylamide gel electrophoresis and Western (immunoblot) analysis with antibodies developed against the NC-FP (data not shown). Infiltration of partially cleaved N-TEV-C-FP into TAM-105 (sensitive) or Norkan (sensitive) leaves did not result in a detectable change in the amount of necrosis-inducing activity.

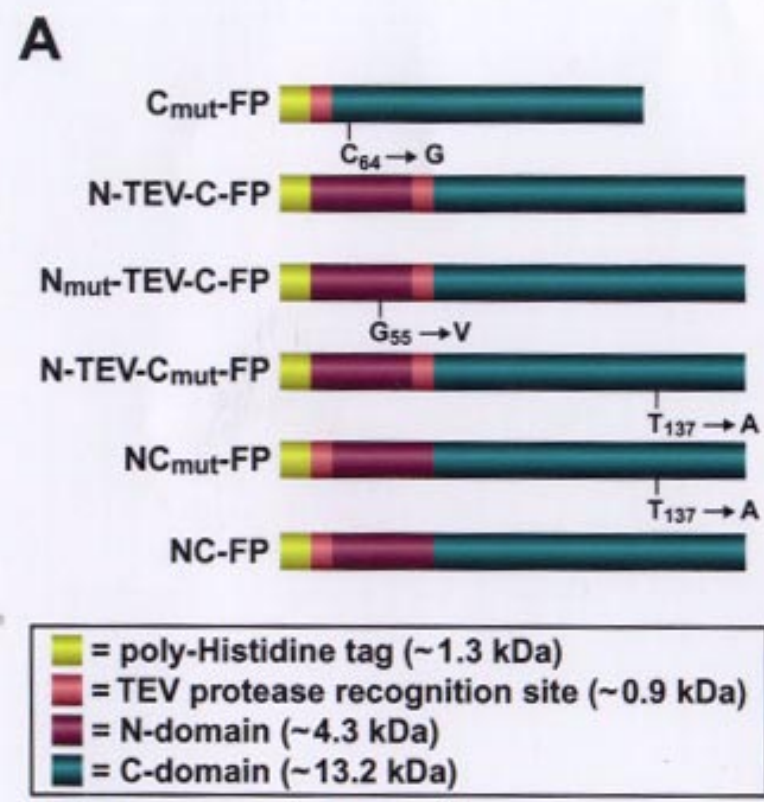

B

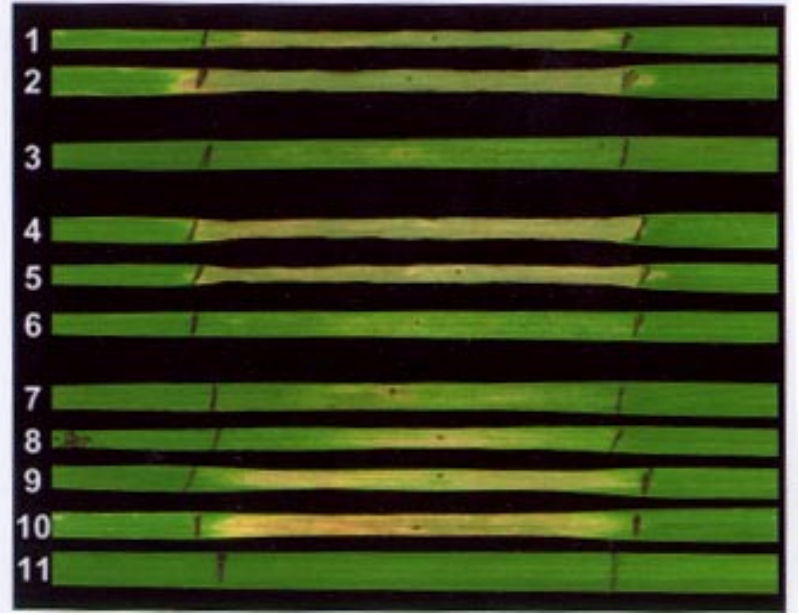

Fig. 3. Structure and bioassay of mutant fusion proteins. A, Fusion protein constructs. An illustration of the mutant fusion proteins expressed in Escherichia coli is shown with the constituent domains of the ToxA open reading frame and locations of the polyhistidine tag and TEV protease recognition motif indicated. B, Leaf infiltration bioassay of mutant fusion proteins. Leaves $1-10$ are sensitive wheat genotype (TAM-105); leaf 11 is insensitive genotype (Auburn). Leaf 1 is infiltrated with Ptr ToxA; leaf 2 with NC-FP; leaf 3 with Cmut-FP; leaf 4 with N-TEV-C-FP; leaf 5 with Nmut-TEV-C-FP; leaf 6 with N-TEV-Cmut-FP (all at $1 \mu \mathrm{M}$ ). Leaves $7-11$ are infiltrated with NCmut-FP: leaf $7(1 \mu \mathrm{M})$; leaf $8(2 \mu \mathrm{M})$; leaf $9(5 \mu \mathrm{M})$; leaves 10 and $11(10 \mu \mathrm{M})$. 
To assess the importance of the presumed disulfide bond within Ptr ToxA, a construct was designed to express a mutant form of the C-FP with the cysteine residue at position $64 \mathrm{mu}$ tated to glycine. The $\mathrm{C}_{\text {mut }}$-FP (Fig. 3A) was refolded and purified in the same way as the C-FP, yielding similar quantities of protein. The $\mathrm{C}_{\mathrm{mut}}-\mathrm{FP}$ appears as the predicted size band (approximately $15.4 \mathrm{kDa}$ ) in SDS-polyacrylamide gels and reacts with antisera raised against purified Ptr ToxA in Western analysis (Fig. 2), but does not elicit necrosis in leaf infiltration bioassays (Fig. 3B), even at high concentrations (10 $\mu \mathrm{M})$ (data not shown).

Several other polymerase chain reaction (PCR)-induced mutations were detected during sequencing of plasmid inserts from bacterial colonies that expressed N-TEV-C-FP. One of these colonies produced a fusion protein of the expected size and antigenicity; however, following refolding, the protein induced only minimal necrosis in the sensitive wheat cultivar (TAM 105). The plasmid (pCT75-3) was sequenced and found to have two mutations, one in the $\mathrm{N}$ domain (Gly-55 to Val) and the other in the C domain (Thr-137 to Ala). The mutations were physically separated by exchanging a restriction fragment of pCT75-3 (containing the mutations) with that of pCT75-19 (containing the wild-type ORF), and vice versa. The resulting plasmids, pCT78 and pCT80, encode the mutant proteins $\mathrm{N}_{\text {mut }}$ TEV-C-FP and $\mathrm{N}$ TEV-C $\mathrm{Cut}_{\text {mut }}$-FP, respectively (Fig. 3A). Both fusion proteins were purified and refolded as established for the NC-FP, and each yielded equivalent amounts of soluble protein. The $\mathrm{N}_{\text {mut }}$-TEV-C-FP elicits a level of necrosis upon infiltration into leaves of TAM 105 (sensitive) similar to that elicited by the N-TEV-C-FP, while the N-TEV-C mut FP has a significantly reduced level of necrosis-inducing activity (Fig. 3B). To assure that the reduction of activity in N-TEV-C ${ }_{\text {mut }}-\mathrm{FP}$ was not due to the presence of the TEV site between the $\mathrm{N}$ and $\mathrm{C}$ domains, a construct was developed that would express a fusion protein exactly the same as the NC-FP, with the exception of the single amino acid change. This was accomplished by exchanging a restriction fragment from pCT68 (containing the wild-type ORF) with the homologous fragment of pCT75-3 (containing the $\mathrm{C}$ domain mutation). The resulting plasmid, pCT79, encodes the mutant proteins $\mathrm{NC}_{\text {mut }}$-FP (Fig. 3A). $\mathrm{NC}_{\text {mut }}$-FP was refolded as established for the NC-FP, and yielded equivalent amounts of soluble protein. $\mathrm{NC}_{\text {mut }}-\mathrm{FP}$ appears as the predicted size band (approximately $19.7 \mathrm{kDa}$ ) in SDS-polyacrylamide gels and reacts with antisera raised against purified Ptr ToxA in protein gel blot analysis (Fig. 2). When $\mathrm{NC}_{\text {mut }}$-FP is infiltrated at a standard working concentration of approximately $1 \mu \mathrm{M}$ (a concentration above which the necrosis-inducing ability of Ptr ToxA is essentially saturated) only minor symptoms are observed, which include a slight upward curling of the leaf blade within the area of infiltration. At elevated concentration (greater than $1 \mu \mathrm{M}$ ), increasing chlorosis occurs and at high concentrations (greater than $10 \mu \mathrm{M}$ ) this chlorosis leads to necrosis after several days (Fig. 3B). Two additional PCR-induced mutations in the $\mathrm{N}$ domain (Arg-54 to Leu, and Gln-58 to His) were also detected during screening for expression of the N-TEV-C-FP. Both were similar to the mutation in the $\mathrm{N}_{\text {mut }}-\mathrm{TEV}-\mathrm{C}-\mathrm{FP}$, in that no apparent effect on the activity of the refolded fusion protein was observed (data not shown).

\section{DISCUSSION}

This study describes the heterologous production of active forms of the Ptr ToxA protein. A previous result indicated that expression of a full-length cDNA of ToxA (syn. PtrNEC) in E. coli resulted in the expression of soluble activity (Ballance et al. 1996). In this study, NC-FP and C-FP were found almost exclusively in the insoluble fraction. The renatured NC-FP can be purified from $E$. coli cells at approximately two to three times the quantities that Ptr ToxA is purified from cultures of $P$. tritici-repentis and with less technical effort. The specific activity of NC-FP is equivalent to that of native Ptr ToxA. Although results from the leaf infiltration assay are difficult to quantitate, the specific activity of C-FP appears to be approximately 10 to $20 \%$ that of native Ptr ToxA and NC-FP (Fig. 1B). Comparisons of the activity of fusion proteins to native Ptr ToxA were based on the results of dilution-series infiltration experiments (Tuori et al. 1995) for each protein, which were repeated multiple times with equivalent results (data not shown). We therefore conclude that the $\mathrm{N}$ domain is necessary for maximum activity of the protein and that a probable function of the $\mathrm{N}$ domain is to aid in the correct folding of the $\mathrm{C}$ domain. The equivalent activity of the NCFP, in comparison to native Ptr ToxA, indicated that it will be useful for routine screening of wheat cultivars for toxin sensitivity, eliminating the need for both standard toxin purification and/or conidial inoculations to screen for disease susceptibility.

The fact that the NC-FP and not the C-FP is fully active was initially surprising, but not, however, without precedent. Several pro-proteins have been expressed as active forms while expression of the mature portion yields protein with little or no activity (Fukuda et al. 1994; Doyle and Smith 1996). Indeed, pro-sequences appear to be particularly important for in vitro refolding. The pro-sequence of Rhizopus niveus extracellular aspartic proteinase-I was shown to be essential for refolding of the denatured mature enzyme in vitro (Fukuda et al. 1994). Similarly, expression studies in E. coli with the Phanerochaete chrysosporium lignin peroxidase isoenzyme H8 pro-protein yielded active enzyme whereas the mature sequences resulted in inactive enzyme following in vitro refolding (Doyle and Smith 1996). Another common function attributed to pro-sequences is in the prevention of possible damaging activity of the mature protein prior to proteolytic cleavage, as was suggested for the Rhizopus oryzae extracellular lipase (Beer et al. 1996). In contrast, this is likely not the case with the pro-sequences from both Ptr ToxA and the cytotoxic protein restrictocin, produced by Aspergillus restrictus. Active pro-restrictocin was produced both in a heterologous in vivo system and in coupled in vitro transcription and translations, indicating the pro-region plays no role in inactivating this protein (Yang and Kenealy 1992). Therefore, the results of over-expression and in vitro refolding of the C-FP and NCFP indicate that the $\mathrm{N}$ domain appears not to function in suppressing activity prior to ultimate processing, but possibly facilitates the correct folding of the pro-toxin, at least in vitro and in cis.

We are confident that the correct $\mathrm{N}$ terminus of the $\mathrm{C}$ domain was selected for this study, and that the limited activity of the C-FP is not due to omitted amino acids, because Nterminal amino acid sequence of Ptr ToxA was obtained fol- 
lowing enzymatic removal of the inferred N-terminal blockage. Alternatively, the presence of the TEV protease recognition site and HIS-tag immediately adjacent to the $\mathrm{C}$ domain on the C-FP might interfere with the interaction of the C-FP with a potential wheat receptor, thereby causing reduced activity. However, enzymatic removal of the HIS-tag with TEV protease did not result in an increase in the activity of the C-FP (data not shown). In addition, the presence of the TEV site adjacent to the $\mathrm{C}$ domain in the N-TEV-C-FP had no apparent effect on the activity of that protein. It is most likely that the $\mathrm{C}$ domain, without the $\mathrm{N}$ domain in cis, has a limited capability for assuming the correct conformation. Only partial activity was obtained when purified, native Ptr ToxA was reduced and then subjected to the same in vitro refolding procedure used on the fusion proteins (data not shown). However, full activity was obtained when Ptr ToxA was not reduced prior to refolding, indicating that the formation of the disulfide bond is the essential, limiting step.

The recovery of active NC-FP from E. coli also indicates that whatever in vivo post-translational or co-translational processing may occur to this protein prior to secretion is not essential for activity. Indeed, it is most likely that no extensive modifications of Ptr ToxA occur at all. Mass spectral analysis indicates a molecular mass of $13,208 \mathrm{Da}( \pm 2)$ for the mature Ptr ToxA (Tuori et al. 1995). Molecular mass calculations for the predicted polypeptide from the ToxA ORF indicate that the most likely proteolytic cleavage site within the protoxin would occur after Arg-60, resulting in a mature Ptr ToxA with Gln61 at its $\mathrm{N}$ terminus (Ciuffetti et al. 1997). The cyclization of a glutamine residue at the $\mathrm{N}$ terminus of a protein, either spontaneously or enzymatically, can result in the formation of a pyroglutamate residue (Harris 1989). We demonstrated that the $\mathrm{N}$ terminus of Ptr ToxA is a pyroglutamate residue. The mass decreases resulting from the formation of a single disulfide bond (2 Da, see below) and pyroglutamate formation at the $\mathrm{N}$ terminus (17 $\mathrm{Da}$ ) would yield a polypeptide with a molecular mass of 13,194 Da. Also, a common modification occurring during MALDI-TOF analyses of proteins is the oxidation of a methionine residue to methionine sulfoxide, resulting in a mass increase of $16 \mathrm{Da}$. Such a modification would yield a polypeptide with a molecular mass of $13,210 \mathrm{Da}$, extremely close to the determination for Ptr ToxA (13,208 Da). Therefore, the mass spectral data, in conjunction with the results of $\mathrm{N}$-terminal sequencing of Ptr ToxA and the heterologous expression studies, indicate that post-translational modifications of the $\mathrm{C}$ domain are unlikely.

Because the ToxA ORF predicts two cysteine residues (positions 64 and 160) within the $\mathrm{C}$ domain, and heat in the presence of reducing agents eliminates virtually all toxic activity of Ptr ToxA (Fig. 1C), a disulfide bond within Ptr ToxA that is essential for activity is indicated. The fact that $\mathrm{C}_{\mathrm{mut}}-\mathrm{FP}$ with a mutation at residue Cys-64 is completely inactive provides further evidence for an essential disulfide bond within Ptr ToxA (Fig. 3B).

Although too few mutations were generated to provide an exhaustive structure/function study, this work demonstrates the utility of the heterologous system for further such experiments, as both active and inactive mutant forms of the toxin could be discriminated when expressed in E. coli. Most interestingly, the single amino acid mutation in the $\mathrm{NC}_{\mathrm{mut}}$-FP significantly reduced the necrosis-inducing ability of this protein.
Based on the leaf infiltration bioassay, $\mathrm{NC}_{\text {mut }}$-FP appears to be approximately 5 to $10 \%$ as active as the NC-FP and produced significantly different symptoms (notably more chlorosis). The mutation, Thr-137 to Ala, is proximal to an "RGD" motif (amino acid residues 140 to 142), an amino acid sequence that, in some proteins, is important in cell surface proteinprotein interactions (Ruoslahti and Pierschbacher 1986). Sitedirected mutagenesis of the RGD motif, as well as other potentially interesting regions of the protein, is in progress.

It appears that the NC-FP, in conjunction with the $\mathrm{NC}_{\mathrm{mut}} \mathrm{FP}$, will be a useful tool for binding studies to identify a potential wheat receptor protein. Both proteins can be purified in abundance, and while the NC-FP has activity similar to that of Ptr ToxA, the $\mathrm{NC}_{\mathrm{mut}}-\mathrm{FP}$ is significantly less active. Presumably, this mutant protein will also be significantly impaired in its ability to bind to the wheat protein(s) necessary for eliciting necrosis and, thus, provides a useful control to distinguish between specific and nonspecific interactions. NC-FP may be advantageous over native Ptr ToxA for receptor-binding experiments because the $\mathrm{N}$ domain has two lysine residues, which can be specifically biotinylated and, if necessary, iodinated. This will permit several methods of detection and affinity-isolation of the protein, and potentially its receptor. In addition, because antibodies have been developed against the NC-FP, it may be a useful tool for assessing whether the mature toxin undergoes any detectable processing in planta, such as proteolytic cleavage, as both regions of the bipartite fusion protein can be immunologically detected.

Mass spectral analysis combined with $\mathrm{N}$-terminal protein sequence analysis of the NC-FP indicates that this protein (i) is unblocked and therefore has a free amino group at its $\mathrm{N}$ terminus, and (ii) has a mass of 19,801 Da, with an apparent unexpected mass increase of $16 \mathrm{Da}$, and therefore very likely does not have modifications to the two lysine residues within the $\mathrm{N}$ domain. Carbamoylation, with a mass increase of 43 $\mathrm{Da}$, is a common modification to the $\varepsilon$-amino group of lysine residues in proteins that have been exposed to high concentrations of urea. This was a concern, because urea was used during in vitro refolding and one of our goals was to produce a protein with lysine residues that could be adducted. The NCFP has three unmodified primary amino groups that could be potentially derivatized. The 16 -Da mass increase is likely due to the oxidation of methionine, as described above.

The question of whether the $\mathrm{N}$ domain is the observed anionic toxic component could not be addressed because adequate quantities were not obtained by heterologous expression. The inability to detect N-FP from lysates of cells harboring pCT71 could be due to toxicity of the peptide in $E$. coli, or instability. Toxicity of certain eukaryotic proteins, however, is not uncommon during prokaryotic expression. A possible toxic activity of the $\mathrm{N}$ domain may be addressable with a eukaryotic expression system. Eukaryotic expression may be particularly important because an N-glycosylation motif is found in the $\mathrm{N}$ domain, and it is possible that this site needs to be modified for any possible toxic activity of the $\mathrm{N}$ domain.

In summary, a fully active form of the Ptr ToxA protein was expressed in E. coli. The NC-FP, consisting of both the N and $\mathrm{C}$ domains of the Ptr ToxA ORF, is as active as native Ptr ToxA, indicating three points: (i) the $\mathrm{N}$ domain is important for maximal activity of the protein, at least when refolded in 
vitro; (ii) the $\mathrm{N}$ domain does not function to eliminate activity prior to proteolytic processing; and, (iii) post-translational processing of Ptr ToxA is not essential for full activity. The NC-FP will be useful both for receptor-binding studies and for screening wheat cultivars for toxin sensitivity.

\section{MATERIALS AND METHODS}

\section{Plasmid construction.}

All expression constructs were produced in the bacterial expression vector pTrc99A (Pharmacia, Piscataway, NJ) that directs the expression of HIS-tagged fusion proteins in E. coli. For each construct, primers were designed such that the PCRamplified portion of the ToxA gene was generated with a $5^{\prime}$ $N c o$ I site and $3^{\prime}$ BamHI site. In addition, all $5^{\prime}$ primers for the generation of insert DNA were designed to encode the TEV protease recognition site. The PCR products were digested with $N c o$ I and BamHI, gel-purified with the QIAquick Gel Extraction Kit (Qiagen, Valencia, CA) and cloned into the $N c o$ I and BamHI sites of pTrc99A. Primer 15 (5'-GGG GCC ATG GGG GAG AAT CTT TAT TTT CAG GGC GAT CCC GGT TAC GAA-3') and primer 14B (5'-GCT TGG ATC CTA ATT TTC TAG CTG CAT TCT-3') were used to amplify the insert for the NC-FP expression vector (pCT68). Primer 23 (5'-GGG GCC ATG GGG GAG AAT CTT TAT TTT CAG GGC $A A A$ CAG GGA AGC TGC ATG TCA-3') and primer 14B were used to amplify the insert for the C-FP expression vector (pCT70). Primer 23 was designed to encode a lysine codon (shown in italics) immediately following the TEV recognition site. This would allow for biotinylation of this fusion protein, as no lysine residues are present in Ptr ToxA. Primer 15 and primer 24 (5'-CCC CGG ATC CTA CCG CTC CTG TAG GAG-3') were used to amplify the insert for the N-FP expression vector (pCT71). For all primers mentioned in this study, bold letters indicate those bases within the primer that encode the TEV recognition site (amino acid sequence GENLYFQ $\uparrow$ G) and underlined letters indicate the NcoI and BamHI restriction sites. Unless otherwise stated, all PCRs were performed with a standard reaction mix $(100 \mathrm{nM}$ each primer, $200 \mu \mathrm{M}$ each dNTP, $1.5 \mathrm{mM} \mathrm{MgCl}_{2}, 1 \times$ Taq reaction buffer, and 1 U Taq DNA polymerase; Promega, Madison, WI). Following $2 \mathrm{~min}$ at $94^{\circ} \mathrm{C}$, reactions were cycled five times through $30 \mathrm{~s}$ at $94^{\circ} \mathrm{C}, 30 \mathrm{~s}$ at $50^{\circ} \mathrm{C}$, and $1 \mathrm{~min}$ at $72^{\circ} \mathrm{C}$, and then an additional 30 times through $30 \mathrm{~s}$ at $94^{\circ} \mathrm{C}, 30 \mathrm{~s}$ at $60^{\circ} \mathrm{C}$, and $1 \mathrm{~min}$ at $72^{\circ} \mathrm{C}$. The template for all PCRs was a chimeric, full-length cDNA clone (pCT37) (Tuori 1998).

The site-directed mutagenesis necessary for the expression of the $\mathrm{C}_{\text {mut }}$-FP was accomplished by designing a $5^{\prime}$ primer for PCR that contained the desired mutation, as well as the NcoI site for cloning and the TEV protease recognition site separating the HIS-tag and ToxA ORF. Primer 27 (5'-GGG GCC ATG GGG GAG AAT CTT TAT TTT CAG GGC $A A A$ CAG GGA AGC GGC ATG TCA-3') and primer 14B were used to amplify the insert for the $\mathrm{C}_{\mathrm{mut}} \mathrm{-FP}$ expression vector (pCT72). PCR products were digested with NcoI and BamHI, gel-purified as described, and cloned into the NcoI and BamHI sites of pTrc99A.

The insert for the plasmid (pCT75) that would direct the expression of the N-TEV-C-FP was generated through initial PCR amplification of the $\mathrm{N}$ and $\mathrm{C}$ domains separately. The primers for this amplification were designed such that the $3^{\prime}$ end of the coding strand of the $\mathrm{N}$ domain product would be complementary to the $5^{\prime}$ end of the noncoding strand of the $\mathrm{C}$ domain product, with the complementary region being the TEV recognition site. The complementary ends were utilized in a second PCR to prime each other and create a full-length product with an internal TEV site. The $\mathrm{N}$ domain was amplified with primer 32 (5'-GGG GCC ATG GAT CCC GGT TAC GAA ATC GTT-3') and primer $30\left(5^{\prime}\right.$-TCC CTG GCC CTG AAA ATA AAG ATT CTC CCC CCG CTC CTG TAG GAG TCC GCG-3'). The C domain was amplified with primer 31 (5'-GAG CGG GGG GAG AAT CTT TAT TTT CAG GGC CAG GGA AGC TGC ATG TCA ATC-3') and primer $14 \mathrm{~b}$. The two PCR products were gel-purified as described, and approximately $10 \mathrm{ng}$ of each was then used for a second PCR in standard PCR mix, with the exception that no primers were used in the reaction. Following $2 \mathrm{~min}$ at $94^{\circ} \mathrm{C}$, the reaction was cycled two times through $30 \mathrm{~s}$ at $94^{\circ} \mathrm{C}, 30 \mathrm{~s}$ at $50^{\circ} \mathrm{C}$, and $1 \mathrm{~min}$ at $72^{\circ} \mathrm{C}$, and then an additional three cycles through $30 \mathrm{~s}$ at $94^{\circ} \mathrm{C}, 30 \mathrm{~s}$ at $60^{\circ} \mathrm{C}$, and $1 \mathrm{~min}$ at $72^{\circ} \mathrm{C}$. The 50- $\mu$ PCR was then supplemented with stocks of primers 32 and 14B, dNTPs, $\mathrm{MgCl}_{2}, 10 \times$ buffer, and Taq DNA polymerase such that the final volume of $100 \mu \mathrm{l}$ was a standard PCR mix. The reaction was cycled 30 times through $30 \mathrm{~s}$ at $94^{\circ} \mathrm{C}, 30 \mathrm{~s}$ at $60^{\circ} \mathrm{C}$, and $1 \mathrm{~min}$ at $72^{\circ} \mathrm{C}$. The full-length, NTEV-C PCR product was gel-purified, digested with BamHI and NcoI, and cloned into the NcoI and BamHI sites of pTrc99A, resulting in pCT75.

The two mutations of pCT75-3 were physically separated by virtue of a SalI site within the ORF (separating the mutations) and an additional SalI site adjacent to the BamHI site of the polylinker in the parent vector (pTrc99A). This allowed for plasmids containing single mutations to be constructed by exchanging the SalI fragment of pCT75-3 (containing the C domain mutation) with the equivalent fragment of pCT75-19 (containing the wild-type $\mathrm{C}$ domain). This resulted in plasmid pCT80, which encodes the mutant protein $\mathrm{N}-\mathrm{TEV}-\mathrm{C}_{\text {mut }} \mathrm{FP}$, and plasmid pCT78, which encodes the mutant protein $\mathrm{N}_{\text {mut }}{ }^{-}$ TEV-C-FP. Exchanging the SalI fragment from pCT75-3 (containing the $\mathrm{C}$ domain mutation) with the equivalent fragment of pCT68 (containing the wild-type $\mathrm{C}$ domain) produced the $\mathrm{NC}_{\text {mut }}-\mathrm{FP}$. This resulted in plasmid pCT79. All constructs were confirmed by direct sequence analyses.

All ligations and bacterial transformations were performed as described by Sambrook et al. (1989). Plasmids were transformed into E. coli cells (BL21[DE3] pLys) carrying the gene for $\mathrm{T} 7$ lysozyme. Colonies expressing the NC-FP, C-FP, N-TEV-C-FP, and any of the mutant fusion proteins were screened for protein production by conventional colony blot procedures (Sambrook et al. 1989) with anti-Ptr ToxA polyclonal antisera and alkaline phosphataseconjugated secondary antibody (Promega). Colonies expressing the N-FP were screened with an alkaline phosphatase-nickel conjugate, NiNTA-AP (Qiagen) according to the manufacturer's suggestions.

Isolation of insoluble proteins from $E$. coli cultures.

E. coli cultures harboring all expression constructs were grown overnight in $5 \mathrm{ml}$ of LB (Sambrook et al. 1989) with $100 \mu \mathrm{g}$ of ampicillin per $\mathrm{ml}(\mathrm{LBA})$ at $37^{\circ} \mathrm{C}$ with shaking at $250 \mathrm{rpm}$ (G24 Incubator Shaker, New Brunswick Scientific, Edison, NJ). Two-hundred and fifty microliters of the over- 
night culture was used to inoculate $25 \mathrm{ml}$ of fresh LBA and incubated with shaking at $37^{\circ} \mathrm{C}$ for $1 \mathrm{~h}$. Expression of fusion proteins was induced by addition of isopropyl-beta-Dthiogalactopyranoside (IPTG), to a final concentration of 1 $\mathrm{mM}$, and the cultures were incubated for an additional $4 \mathrm{~h}$ under the same conditions. Cells were harvested by centrifugation at $4,000 \times g, 4^{\circ} \mathrm{C}$ for $20 \mathrm{~min}$ and the pellets were resuspended in cold sonication buffer $\left(\mathrm{SB} ; 50 \mathrm{mM} \mathrm{Na} \mathrm{HPO}_{4}, 5\right.$ $\mathrm{mM}$ Tris-base, $300 \mathrm{mM} \mathrm{NaCl}, \mathrm{pH} 8.0$ ) with $0.5 \%$ Triton-x100 and $10 \mathrm{mM}$ DTT. Resuspended pellets were sonicated three times, $30 \mathrm{~s}$ each, with $2 \mathrm{~min}$ on ice between periods. Insoluble material was then pelleted by centrifugation at 10,000 $\times g$, $4^{\circ} \mathrm{C}$, for $10 \mathrm{~min}$. Pellets were washed three times with $\mathrm{SB}$ with $0.5 \%$ Triton-x-100 and $10 \mathrm{mM}$ DTT, and three times with SB with $10 \mathrm{mM}$ DTT. The final washed pellets, containing inclusion bodies, were either stored frozen at $-80^{\circ} \mathrm{C}$ or resuspended in $1 \mathrm{ml}$ of $8 \mathrm{M}$ guanidine $\mathrm{HCl}$ (Sigma) in refolding buffer $(250 \mathrm{mM} \mathrm{NaCl}, 100 \mathrm{mM}$ sodium phosphate buffer, 10 $\mathrm{mM}$ Tris-base, 4\% glycerol, $1 \mathrm{mM}$ EDTA, and $0.005 \%$ Tween 20, pH 8.0) with freshly prepared DTT added to a final concentration of $10 \mathrm{mM}$. Solubilized proteins were sonicated briefly twice (for 5 to $10 \mathrm{~s}$ ) and then heated to $37^{\circ} \mathrm{C}$ for 10 min and $50^{\circ} \mathrm{C}$ for an additional $5 \mathrm{~min}$ to assist in solubilization of proteins. Insoluble material was removed from the samples by centrifuging at $12,000 \times g$ for $10 \mathrm{~min}$, and then solubilized proteins were quantitated with Bradford assay reagent (Bio-Rad, Hercules, CA) with bovine serum albumin used as a standard. Fusion proteins solubilized in guanidine $\mathrm{HCl}$ were used immediately.

\section{Fusion protein refolding.}

In vitro refolding was accomplished in dialysis tubing with decreasing concentrations of urea used to maintain protein solubility. All urea (Bio-Rad) used during this study was deionized with AG-501-X8 mixed-bed resin (Bio-Rad) according to the manufacturer's directions and degassed under vacuum. All water used during this study was obtained from a Barnstead E-pure system. Dialysis buffers were prepared by diluting a freshly prepared $8 \mathrm{M}$ urea solution with water and $5 \times$ refolding buffer to give the appropriate urea concentration in $1 \times$ refolding buffer. All but the final dialysis buffer also contained $10 \mathrm{mM}$ ethylene diamine (ED, Sigma) added from a $1 \mathrm{M}$ stock as a scavenger of cyanate ions. The $\mathrm{pH}$ was adjusted to 8.0 and the solution was purged of $\mathrm{O}_{2}$ by bubbling with $\mathrm{N}_{2}$ for approximately $2 \mathrm{~min}$. Buffers were either used immediately or stored at $-20^{\circ} \mathrm{C}$ for use within a few days. The amount of activity recovered with the NC-FP was independent of the redox state in the dialysis refolding procedure, while consistent activity was obtained from the C-FP only when redox reagents were absent from the refolding procedure. Therefore, after initial experiments, redox reagents were omitted from all in vitro refolding experiments. The following describes the standard, analytical scale, refolding protocol used when testing all fusion proteins for activity. Prior to refolding, solubilized fusion protein samples were diluted with $8 \mathrm{M}$ guanidine $\mathrm{HCl}$ (stored at $4^{\circ} \mathrm{C}$ ), $5 \times$ refolding buffer, water, and 1 $M$ ED such that the final volume was $1 \mathrm{ml}$ and the final protein concentration was $100 \mathrm{ng} / \mu \mathrm{l}$ in $1 \times$ refolding buffer with 6 $\mathrm{M}$ guanidine $\mathrm{HCl}$ and $10 \mathrm{mM} \mathrm{ED}$. All dialyses were performed in beakers at $4^{\circ} \mathrm{C}$, stirring slowly against $100 \mathrm{ml}$ of refolding buffer containing decreasing amounts of urea. The samples were applied into an 11.5-mm-wide SpectraPor 3500 MW cut-off membrane and dialyzed for approximately $4 \mathrm{~h}$ to remove residual DTT against $1 \times$ refolding buffer with $6 \mathrm{M}$ urea and $10 \mathrm{mM}$ ED. The buffer was replaced with $1 \times$ refolding buffer with $4 \mathrm{M}$ urea and $10 \mathrm{mM}$ ED and dialyzed for an additional $24 \mathrm{~h}$. This was done again with $1 \times$ refolding buffer with $2 \mathrm{M}$ urea and $10 \mathrm{mM} \mathrm{ED}$, and again with $1 \times$ refolding buffer with $10 \mathrm{mM}$ ED but without urea. Finally, the samples were dialyzed an additional $4 \mathrm{~h}$ against $100 \mathrm{ml}$ of $1 \times$ refolding buffer with neither ED nor urea. Refolding experiments that included reducing and oxidizing reagents contained $2 \mathrm{mM}$ reduced glutathione (Sigma) and $0.02 \mathrm{mM}$ oxidized glutathione (Sigma) throughout the dialyses except for the last dialysis step, in which both were omitted. Following the final dialysis, insoluble proteins were removed from samples by centrifuging at $12,000 \times g$ for $10 \mathrm{~min}$ and transferring the supernatant to a new tube. Samples were then assayed for necrosis-inducing activity by infiltrating into sensitive (TAM-105) and insensitive (Auburn) wheat cultivars, as described (Tuori et al. 1995). N-TEV-C-FP, following digestion with TEV protease, was also infiltrated into wheat cultivar Norkan (sensitive), the cultivar used in a previous study to assay for the anionic toxic component (Tuori et al. 1995). TEV protease was obtained from GibcoBRL (Rockville, MD) and used according to the manufacturer's instructions except that $10 \mathrm{mM} \beta$-mercaptoethanol instead of dithiothreitol (DTT) was used, and reactions were performed at $16^{\circ} \mathrm{C}$ overnight.

Larger, preparative scale, production of both NC-FP and $\mathrm{NC}_{\text {mut }}$-FP was performed essentially as described above but with the following modifications. Generally, $250 \mathrm{ml}$ of bacterial culture was induced, grown, and harvested as described. Cell pellets were then resuspended in $60 \mathrm{ml}$ of SB with $0.5 \%$ Triton-X-100 and $10 \mathrm{mM}$ DTT, transferred to smaller $(30 \mathrm{ml})$ centrifuge tubes and sonicated. Insoluble protein pellets were washed three times with $30 \mathrm{ml}$ of SB with $0.5 \%$ Triton-x-100 and $10 \mathrm{mM}$ DTT, and then three times with $30 \mathrm{ml}$ of SB with $10 \mathrm{mM}$ DTT. The final pellets were solubilized with $10 \mathrm{ml}$ of $8 \mathrm{M}$ guanidine $\mathrm{HCl}$ in refolding buffer with freshly prepared DTT added to a final concentration of $10 \mathrm{mM}$. In vitro refolding was accomplished in 34-mm-wide dialysis membrane, generally with 1 liter of dialysis buffer volume for each dialysis step.

\section{Purification of HIS-tagged fusion proteins.}

HIS-tagged fusion proteins were purified to near homogeneity with NiNTA Agarose resin (Qiagen). Protein samples were prepared for NiNTA agarose binding by dialyzing against $\mathrm{Ni}$ Buffer $(250 \mathrm{mM} \mathrm{NaCl}, 100 \mathrm{mM}$ sodium phosphate buffer, and 4\% glycerol, $\mathrm{pH}$ 8.0) in $3500 \mathrm{MW}$ cut-off dialysis membranes for approximately $24 \mathrm{~h}$ with three buffer changes to remove residual Tris, EDTA, and ED. After dialyses, the samples were centrifuged to remove insoluble proteins and quantitated as described. NiNTA agarose resin was used at approximately $400 \mu \mathrm{l}$ of resin $(1: 1$ in $\mathrm{Ni}$ Buffer with $1 \%$ Tween 20, $\mathrm{pH} 8.0$ ) per $\mathrm{mg}$ of protein. The resin was equilibrated for $1 \mathrm{~h}$ in Ni Buffer with 1\% Tween 20, pH 8.0 prior to binding. The samples were brought up to a final concentration of $1 \%$ Tween 20 ( $\mathrm{vol} / \mathrm{vol})$ with the addition of $25 \%$ Tween 20 in Ni Buffer, $\mathrm{pH} 8.0$, and equilibrated resin was added to the samples. Binding of HIS-tagged proteins to the resin was accomplished by batch capture, overnight, stirring slowly at 
$4^{\circ} \mathrm{C}$. Samples were poured into either a 1-cm-diameter column for standard preps or a 3-cm-diameter column for larger preps, and the flow-through was collected. The resin was washed twice with one column volume of wash 1 (Ni Buffer with 1 $\mathrm{mM}$ imidazole [Sigma], $\mathrm{pH}$ 8.0), twice with one column volume wash 2 (Ni Buffer with $10 \mathrm{mM}$ imidazole, $\mathrm{pH}$ 8.0), twice with one column volume wash 3 (Ni Buffer with $500 \mathrm{mM}$ imidazole, $\mathrm{pH} 8.0$ ), and twice with one column volume wash 4 (Ni Buffer with $10 \mathrm{mM}$ EDTA, pH 8.0). The flow-through and washes were analyzed by both gel electrophoresis and the leaf infiltration bioassay. SDS-polyacrylamide gel electrophoresis (PAGE) and Western analyses were performed as described (Tuori et al. 1995) with proteins separated in a $17 \%$ SDS-polyacrylamide gel and visualized by staining with Brilliant Blue-G Colloidal Concentrate (Sigma).

Prior to both the mass spectral analysis and the N-terminal amino acid sequencing of NC-FP, purified protein was dialyzed against $100 \mathrm{mM} \mathrm{Na} \mathrm{HCO}_{3}$ to remove imidazole. Mass spectral analysis (MALDI-TOF) was performed at the Mass Spectrometry Lab at Oregon State University. For amino acid sequencing, NC-FP was applied to a ProSorb cartridge (PE Biosystems, Foster City, CA) as directed by the manufacturer. Sequence determination was performed at the Biotechnology $\mathrm{Lab}$ at the Institute for Molecular Biology, University of Oregon. Antiserum against refolded, purified NC-FP was raised at Bioworld (Dublin, OH).

\section{Determination of the $\mathbf{N}$ terminus of the mature Ptr ToxA protein.}

Prior to treatment with the enzyme pyroglutamate amino peptidase, the cysteine residues of Ptr ToxA were reduced and alkylated. Ten nanomoles of lyophilized Ptr ToxA was dissolved in $150 \mu \mathrm{l}$ of alkylation buffer $(0.2 \mathrm{M}$ Tris, $\mathrm{pH} 8.4$, $100 \mathrm{mM}$ DTT, $1 \%$ SDS) and incubated at $70^{\circ} \mathrm{C}$ for $20 \mathrm{~min}$. The sample was then diluted with four volumes of double distilled water and dimethylacrylamide (Aldrich, Milwaukee, WI) was added from a $9.7 \mathrm{M}$ stock to a final concentration of $2 \mathrm{M}$. The reaction was incubated under argon for 1 $\mathrm{h}$ at $37^{\circ} \mathrm{C}$ in the dark, after which the unreacted dimethylacrylamide was quenched with the addition of $10 \% \beta$ mercaptoethanol to a final concentration of $0.25 \%$. The volume was brought up to $2 \mathrm{ml}$ with pyroglutamate amino peptidase buffer $\left(100 \mathrm{mM} \mathrm{K}_{2} \mathrm{HPO}_{4}, 10 \mathrm{mM}\right.$ EDTA, 5\% glycerol and $5 \mathrm{mM}$ DTT with the $\mathrm{pH}$ adjusted to 8.0 with $1 \mathrm{M} \mathrm{HCl}$ ) and the sample was concentrated in a Centricon-3 microconcentrator (Millipore, Bedford, MA) for $2 \mathrm{~h}$, spinning at $7,500 \times g, 25^{\circ} \mathrm{C}$. This was done a second time for further buffer exchange. After the second spin, the sample was brought up to $1.1 \mathrm{ml}$ with pyroglutamate amino peptidase buffer and then $100 \mu \mathrm{l}(5 \mathrm{U})$ of pyroglutamate amino peptidase (Sigma) was added such that the final reaction volume was $1.2 \mathrm{ml}$. The reaction was incubated at $37^{\circ} \mathrm{C}$ overnight and then concentrated in a Centricon-3 microconcentrator as described until the volume was reduced to approximately $250 \mu \mathrm{l}$. The sample was applied to a ProSorb cartridge as directed by the manufacturer except that the sample was washed with approximately $750 \mu$ of $0.1 \%$ trifluoroacetic acid following application to the membrane. Following air drying, the sample was subjected to amino acid sequencing at The Institute for Molecular Biology, Protein Sequencing Lab, University of Oregon. This procedure was done two times, with hen egg white lysozyme (Sigma) used as a control protein to aid in the identification of derivatized cysteine peaks during sequencing.

\section{Heat and reduction stability.}

NC-FP and Ptr ToxA at an equivalent concentration of $1 \mu \mathrm{M}$ were treated by boiling for $10 \mathrm{~min}$ with or without $10 \mathrm{mM} \beta$ mercaptoethanol. The samples were cooled and infiltrated. Both proteins were also treated in a reducing environment of $10 \mathrm{mM} \beta$-mercaptoethanol overnight at $4{ }^{\circ} \mathrm{C}$ and then assayed for activity by infiltration.

\section{ACKNOWLEDGMENTS}

We wish to thank Sean Ottum and Adrienne Schackart for technical assistance, and Blaine Baker for help with figures. This research was supported in part by grants from the National Science Foundation (no. 9600914) and the U.S. Department of Agriculture CSREES (no. 9735303-4563).

\section{LITERATURE CITED}

Bailey, K. L., and Duczek, L. J. 1996. Managing cereal diseases under reduced tillage. Can. J. Plant Pathol. 18:159-167.

Ballance, G. M., Lamari, L., and Bernier, C. C. 1989. Purification of a host-selective necrosis toxin from Pyrenophora tritici-repentis. Physiol. Mol. Plant Pathol. 35:203-213

Ballance, G. M., Lamari, L., Kowatsch, R., and Bernier, C. C. 1996. Cloning, expression and occurrence of the gene encoding the Ptr necrosis toxin from Pyrenophora tritici-repentis. Mol. Plant Pathol. Online, publication/1996/1209ballance.

Beer, H. D., Wolhfahrt, G., Schmid, R. D., and McCarthy J. E. G. 1996. The folding and activity of the extracellular lipase of Rhizopus oryzae are modulated by a prosequence. Biochemical J. 319:351-359.

Ciuffetti, L. M., Francl, L. J., Ballance, G. M., Bockus, W. W., Lamari, L., Meinhardt, S. W., and Rasmussen, J. B. 1998. Standardization of toxin nomenclature in the Pyrenophora tritici-repentis/wheat interaction. Can. J. Plant Pathol. 20:421-424.

Ciuffetti, L. M., Tuori, R. P., and Gaventa, J. M. 1997. A single gene encodes a selective toxin causal to the development of tan spot of wheat. Plant Cell 9:135-144.

Cox, T. S., Shroyer, J. P., Ben-Hui, L., Sears, R. G., and Martin, T. J. 1988. Genetic improvement in agronomic traits of hard red winter wheat cultivars from 1919 to 1987 . Crop Sci. 28:756-760.

Doyle, W. A., and Smith, T. A. 1996. Expression of lignin peroxidase $\mathrm{H} 8$ in Escherichia coli: folding and activation of the recombinant enzyme with $\mathrm{CA}^{2+}$ and haem. Biochem. J. 315:15-19.

Eder, J., and Fersht, A. R. 1995. Pro-sequence-assisted protein folding. Mol. Microbiol. 16:609-614.

Francl, L. J. 1995. Challenge of bioassay plants in a monitored outdoor environment. Can. J. Plant Pathol. 17:138-143.

Fukuda, R., Horiuchi, H., Ohta, A., and Takagi, M. 1994. The prosequence of Rhizopus niveus aspartic proteinase-I supports correct refolding and secretion of its mature part in Saccharomyces cerevisiae. J. Biol. Chem. 269:9556-9561.

Harris, R. B. 1989. Processing of prohormone precursor proteins. Arch. Biochem. Biophys. 275:315-333.

Hosford, R. M., Jr. 1982. Tan spot. Pages 1-24 in: Tan Spot of Wheat and Related Diseases. R. M. Hosford, Jr., ed. North Dakota State University, Fargo.

Parks, T. D., Howard, E. D., Wolpert, T. J., Arp, D. J., and Dougherty, W. G. 1995. Expression and purification of a recombinant tobacco etch virus NIa proteinase: Biochemical analyses of the full-length and a naturally occurring truncated proteinase form. Virology 210:194201.

Riede, C. R., Francl, L. J., Anderson, J. A., Jordahl, J. G., and Meinhardt, S. W. 1996. Additional sources of resistance to tan spot of wheat. Crop Sci. 36:771-777.

Ruoslahti, E., and Pierschbacher, M. D. 1986. Arg-Gly-Asp: A versatile cell recognition signal. Cell 44:517-518. 
Sambrook, J., Fritsch, E. F., and Maniatis, T. A. 1989. Molecular Cloning: A Laboratory Manual. 2nd ed. Cold Spring Harbor Laboratory, Cold Spring Harbor, NY.

Schuh, W. 1990. The influence of tillage systems on incidence and spatial pattern of tan spot of wheat. Phytopathology 80:804-807.

Tomas, A., Feng, G. H., Reeck, G. R., Bockus, W. W., and Leach, J. E. 1990. Purification of a cultivar-specific toxin from Pyrenophora tritici-repentis, causal agent of tan spot of wheat. Mol. Plant-Microbe Interact. 3:221-224.

Tuori, R. P. 1998. Molecular characterization of a protein toxin involved in the Pyrenophora tritici-repentis/ wheat interaction. Ph.D. dissert. Oregon State University, Corvallis.
Tuori, R. P., Wolpert, T. J., and Ciuffetti, L. M. 1995. Purification and immunological characterization of toxic components from cultures of Pyrenophora tritici-repentis. Mol. Plant-Microbe Interact. 8:4148.

von Heijne, G. 1986. A new method for predicting signal sequence cleavage sites. Nucleic Acids Res. 14:4683-4690.

Yang, R., and Kenealy, W. R. 1992. Effects of amino-terminal extensions and specific mutations on the activity of restrictocin. J. Biol. Chem. 267:16801-16805.

Zhang, H.-F., Francl, L. J., Jordahl, J. G., and Meinhardt, S. W. 1997. Structural and physical properties of a necrosis-inducing toxin from Pyrenophora tritici-repentis. Phytopathology 87:154-160. 